\title{
KECELAKAAN LALULINTAS : PERLUKAH MENDAPATKAN PERHATIAN KHUSUS?
}

\author{
Muhammad Syahriza ${ }^{1}$ \\ ${ }^{1}$ Bagian Ilmu Kesehatan Masyarakat, Fakultas Kedokteran Universitas Malikussaleh, Aceh- \\ Indonesia
}

Corresponding Author: dr.syah@unimal.ac.id; syahriza60@gmail.com

\begin{abstract}
Abstrak
Kecelakaan lalu lintas menjadi penyebab utama kematian akibat cedera baik di negara berkembang ataupun negara maju. Angka kejadian kecelakaan lalu lintas terus meningkat setiap tahunnya seiring dengan meningkatnya pengguna kenderaan bermotor terutama di negara berkembang dengan pendapatan rendah dan menengah. Tulisan ini bertujuan untuk memberikan gambaran terkait kecelakan lalu lintas yang terjadi di kawasan Asia Tenggara terutama di Negara Indonesia. Metode yang digunakan adalah dengan menganilisa laporan yang berkaitan dengan kecelakaan lalu lintas secara global, regional dan lokal khususnya kasus yang terjadi di Indonesia. Dari laporan yang ada,, kasus kecelakaan lalu lintas di hampir semua negara mengalami peningkatan yang diikuti oleh dampak berupa penignkatan angka kematian (mortality rate) dan kecacatan lama (DisabilityAdjusted Life Years). Kondisi ini menjadi permasalahan yang besar dibidang kesehatan masyarakat. Oleh karena itu, perhatian dari seluruh pihak sangat diharapkan agar penurunan angka ke matian dan kecacatan akibat kecelakaan lalu lintas bisa dicapai sesuai dengan tujuan pembangunan berkelanjutan (SDGs) 2030.
\end{abstract}

Kata Kunci: Disability-Adjusted Life Years; Kecelakaan Lalu Lintas; Mortality Rate; Sustainable Development Goals.

\section{ROAD TRAFFIC ACCIDENTS: DOES IT NEED SPECIAL ATTENTION?}

\begin{abstract}
Abtract
Road Traffic Accidents (RTAs) are the major problems in both developing and developed countries. The numbers of RTAs increase annually and have a closed relationship to the increase of the vehicles especially in the Low and Middle Income Countries. This essay aims to highlight the number of RTAs across the South-east Asia Region especially in Indonesia. The method used in this study is to analyse the report related to the RTAs globally, regionally and locally. As the result, the RTAs has increased across the countries followed by the increased of road mortality rate and Disability-Adjusted Life Years. It becomes the major problem in public health. Therefore, the need for attention from all sectors towards reducing the number of road mortality rate due to traffic accidents can be achieved according to the Sustainable Development Goals (SDGs) 2030.
\end{abstract}

Keyword: Disability-Adjusted Life Years; Road Traffic Accidents; Mortality Rate; Sustainable Development Goals. 


\section{PENDAHULUAN}

Peningkatan jumlah populasi tidak selamanya memberikan dampak positif bagi perkembangan umat manusia. Sering sekali peningkatan jumlah penduduk diikuti oleh meningkatnya permasalahan dalam kehidupan terutama permasalahan dalam bidang kesehatan masyarakat. Salah satu permasalahan besar di bidang kesehatan masyarakat adalah tingginya angka kejadian kecelakaan lalulintas. Selain menjadi penyebab kematian tertinggi di dunia, kecelakaan lalu lintas juga merupakan salah satu penyebab kematian yang paling sering terjadi diantara cedera yang penyebabnya tidak disengaja (unintentional injuries) lainnya seperti cedera akibat terjatuh, tenggelam, terbakar, dan keracunan. Kondisi ini menjadi tantangan besar terhadap target pembangunan berkelanjutan yang tertuang dalam Sustainable Develompment Goals (SDGs) 2030 poin (3.6) yang menyatakan bahwa target penurunan angka kematian akibat kecelakaan lalu lintas secara global sebesar 50\% pada tahun $2020 .{ }^{1}$

Angka kematian akibat kecelakaan lalu lintas terus meningkat setiap tahunnya dan pada tahun 2016 telah mencapai angka 1,35 juta jiwa. ${ }^{2}$ Angka kematian tertinggi terjadi di kawasan Afrika (26,6 per 100.000 penduduk) dan Asia Tenggara (20,7 per 100.000 penduduk). Peningkatan angka kematian akibat kecelakaan lalu lintas terutama terjadi pada negara-negara berkembang yang dominan terletak di kawasan Afrika, Asia Tenggara dan Mediterania Timur. Sedangkan negara-negara maju yang terletak di kawasan Amerika, Eropa, dan Pasifik Barat menunjukkan kecenderungan penurunan angka kermatian akibat kecelakan lalu lintas pada tahun 2016 jika dibanding dengan tahun 2013 lalu. $^{2}$ Indonesia sebagai sebuah negara dengan penduduk keempat terbanyak di dunia mempunyai resiko yang lebih besar untuk meningkatnya angka kematian akibat kecelakaan lalu lintas, terlebih lagi Indonesia merupakan negara berkembang dengan penghasilan menengah (middle income country). ${ }^{3-4}$

Menurut The Organization for Co-operation and Development (OEDC), kecelakaan lalulintas didefinisikan sebagai suatu kecelakaan baik yang terjadi antara satu kenderaan dengan kenderaan lainnya, kenderaan dengan pejalan kaki, kenderaan dengan hewan, atau kenderaan itu sendiri yang terjadi pada jalan umum yang mengakibatkan cedera atau kematian pada satu orang atau lebih. ${ }^{5}$ Di Indonesia, definisi kecelakaan lalu lintas merujuk kepada definisi yang dikeluarkan oleh Lembaga Kepolisian Neraga Republik Indonesia yang tertuang dalam pasal 1 ayat (3) Peraturan Kepala Kepolisian Negara Republik Indonesia Nomor 15 Tahun 2013 Tentang Tata Cara Penanganan Kecelakaan Lalu Lintas yang menjelasakan 
bahwa "Kecelakaan LaluLlintas adalah suatu peristiwa di jalan yang tidak diduga dan tidak disengaja melibatkan kenderaan dengan atau tanpa pengguna jalan lain yang mengakibatkan korban manusia dan/atau kerugian harta benda". ${ }^{6}$

Tulisan ini bertujuan untuk memberikan gambaran terkait angka kejadian kecelakaan lalu lintas di Wilayah Asia Tenggara terutama kejadian kecelakaan lalu lintas yang terjadi di Indonesia. Tulisan ini akan dibagi menjadi tiga bagian, yaitu: (1) Bagian pertama akan membahas tentang besarnya skala permasalahan yang berhubungan dengan kejadian kecelakan lalu lintas yang diikuti dengan faktor resiko dan kelompok yang paling rentan terhadap terjadinya kecelakan lalu lintas; (2) Pada bagian yang kedua, tulisan ini akan membahas usaha yang bisa dilakukan untuk mengurangi angka kejadian dan angka kematian akibat kecelakaan lalu lintas; dan (3) Pada bagian yang ketiga akan memberikan kesimpulan dari uraian yang ada. Tulisan ini menggunakan metode analisis terhadap laporan yang berkaitan dengan kecelekaan lalu lintas dan dampak yang ditimbulkan serta praktik baik yang mulai diterapkan untuk mengurangi angka kejadian kecelakaan lalu lintas.

\section{Besaran Permasalahan yang Berhubungan dengan Kecelakaan Lalu Lintas}

Jumlah kematian yang diakibatkan oleh kecelakaan lalu lintas terus meningkat setiap tahunnya. Meskipun terjadi peningkatan yang signifikan jika dibanding dengan jumlah kematian akibat kecelakaan lalu lintas pada tahun 2013 yang berjumlah sekitar 1,25 juta jiwa, peningkatan yang terjadi tidak terlepas dengan adanya peningkatan dari jumlah populasi dunia dan jumlah pengguna kenderaaan bermotor. $^{7}$ Kondisi ini memberikan kesimpulan yang berbeda apabila angka kematian tersebut dibandingkan dengan jumlah populasi yang beresiko terhadap terjadinya kematian akibat kecelakaan lalu lintas (mortality rate) yaitu terjadi sedikit penurunan dari 18,3 kasus per 100.000 penduduk pada tahun 2013 menjadi 18,2 kasus per 100.000 penduduk pada tahun 2016 (Gambar 1). ${ }^{2}$ Dilihat dari tingkat pendapatan suatu negara, angka kematian akibat kecelakaan lalu lintas berhubungan erat dengan katagori pendapatan dari suatu negara. Negara dengan pendapatan rendah (Low Income Countries) memiliki angka kematian tiga kali lipat lebih tinggi dibanding negara dengan tingkat penghasilan tinggi (High Income Countries) yaitu 27,5 kematian per 100.000 penduduk dibanding dengan 8.3 kematian per 100.000 penduduk. $^{1}$ 


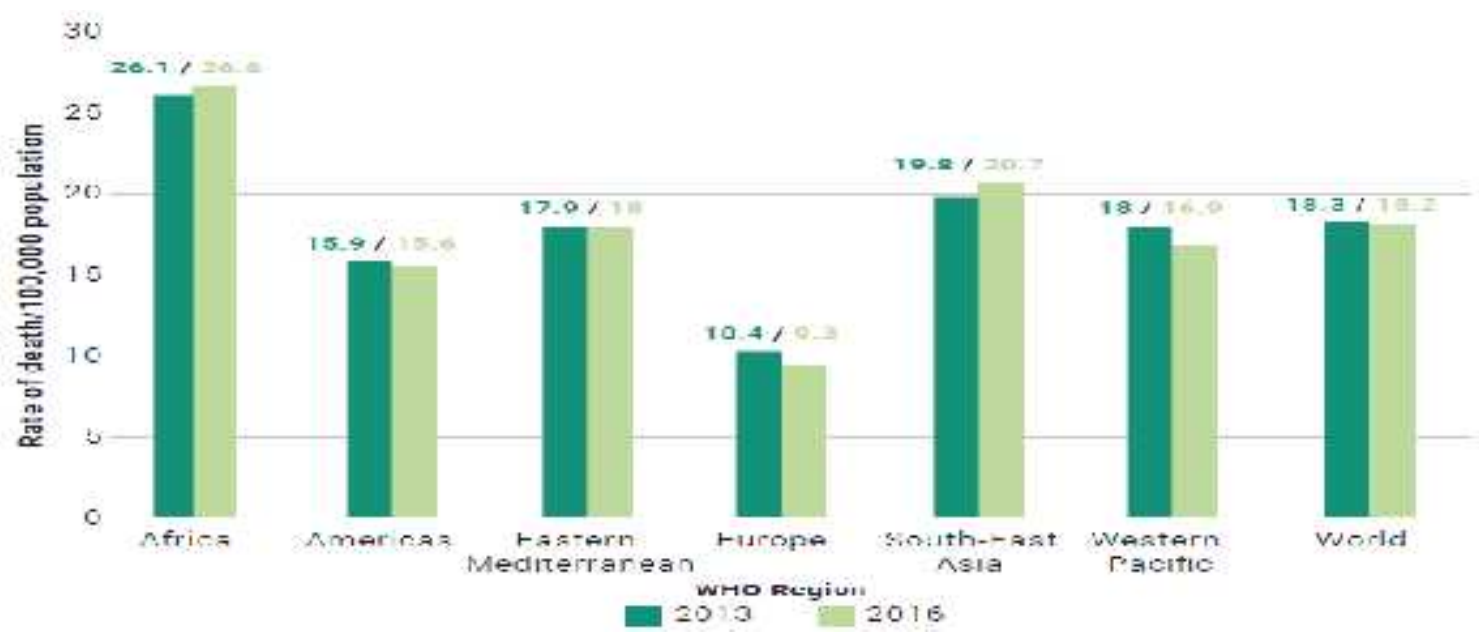

Gambar 1. Angka kematian akibat kecelakaan lalu lintas per 100.000 penduduk berdasarkan kawasan WHO. ${ }^{2}$

Selain itu, diantara 10 penyebab kematian paling sering terjadi pada penduduk usia muda (15-29 tahun) di dunia, kematian akibat kecelakaan lalu lintas merupakan penyebab paling banyak diantara penyakit lainnya yaitu lebih dari 300.000 kematian setiap tahunnya (Gambar 2). ${ }^{7}$

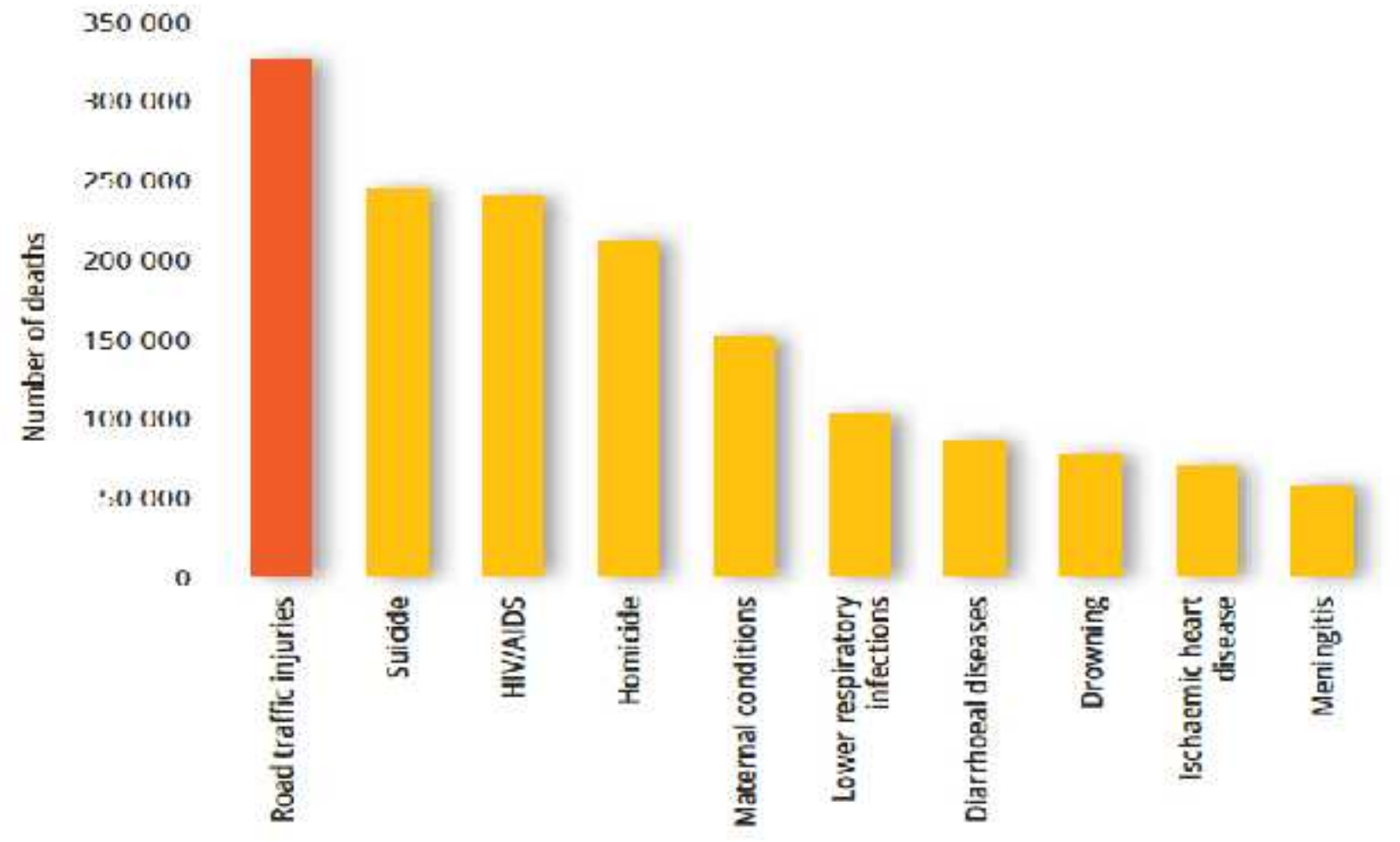

Gambar 2. Sepuluh penyebab utama kematian pada kalangan usia muda (15-29 tahun). ${ }^{7}$

Meskipun demikian, berdasarkan laporan dari Global Burden of Disease Study 2017 menjelaskan bahwa, kematian dini (Years of Live Lost [YLL]) akibat kecelakaan lalu lintas menempati urutan ke-6 pada tahun 2017 dari sebelumnya berada di urutan ke- 8 pada tahun 1990 (Gambar 3). ${ }^{8}$ Sebelumnya, Muray dan Lopez dalam Ameratunga, Hijar, dan Norton 
(2006) menjelaskan bahwa pada tahun 2020 kecelakaan lalu lintas akan menjadi penyebab keamatian tertinggi ke tiga dibanding dengan 9 penyebab lainnya apabila tidak diikuti dengan upaya maksimal dan terintegrasi dari berbagai sector yang berkaitan untuk menurunkan resiko yang ada. ${ }^{9}$

\begin{tabular}{|c|c|}
\hline $1990 \operatorname{rank}^{* *}$ & 2017 rank \\
\hline 1 Neonatal disorders: & 1 lschemic heart disease \\
\hline 2 Lower respiratory infections & 2 Neonatal disonders \\
\hline 3 Disrneal diseases & 3 stroke \\
\hline 4 Ischemic heart disease & 4 Lower tespiratory infections \\
\hline 5 Stroke & 5 Diarrheal diseases \\
\hline 6 Congenital birth defects & 6 Road injuries \\
\hline 7 Tuberculosis & $760 \mathrm{PO}$ \\
\hline 8 Road injuries & 8 HIVIAIDS \\
\hline 9 Messles & 9 Congenital birth defects \\
\hline 10 Molario & 10 Malaria \\
\hline 11 COPD & 11 Tuberculosis \\
\hline 19 HIVIAIOS & 39 Neasles: \\
\hline
\end{tabular}

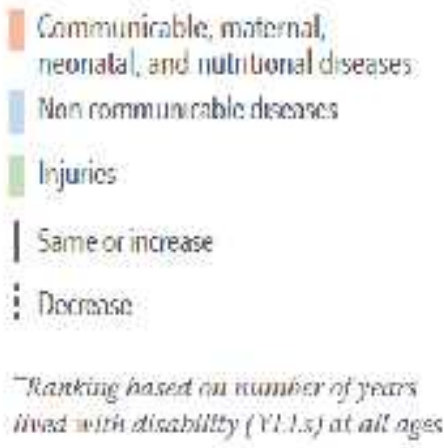

Gambar 3. Penyebab utama kematian dini tahun 1990 dan $2017 .{ }^{8}$

Adapun kecenderungan yang terjadi di kawasan Asia Tenggara (the South-East Asia Region) yaitu terdapat sekitar 316.000 kasus kematian terjadi setiap tahunnya akibat kecelakaan lalu lintas. ${ }^{3}$ Thailand menjadi negara dengan angka kematian tertinggi yaitu 36,2 per 100.000 penduduk. Meskipun bukan menjadi negara dengan angka kematian terendah di Kawasan Asia Tenggara, Indonesia masih termasuk ke dalam negara yang memiliki angka kematian terendah keempat setelah Maladewa (3,5 per 100.000 penduduk), Banglades (13,6 per 100.000 penduduk), dan Bhutan (15,1 per 100.000 penduduk) yaitu sebesar 15,3 per

100.000 penduduk. Angka ini masih berada di bawah angka kematian yang terjadi akibar kecelakaan lalu lintas untuk regional Asia Tenggara (Gambar 4). 


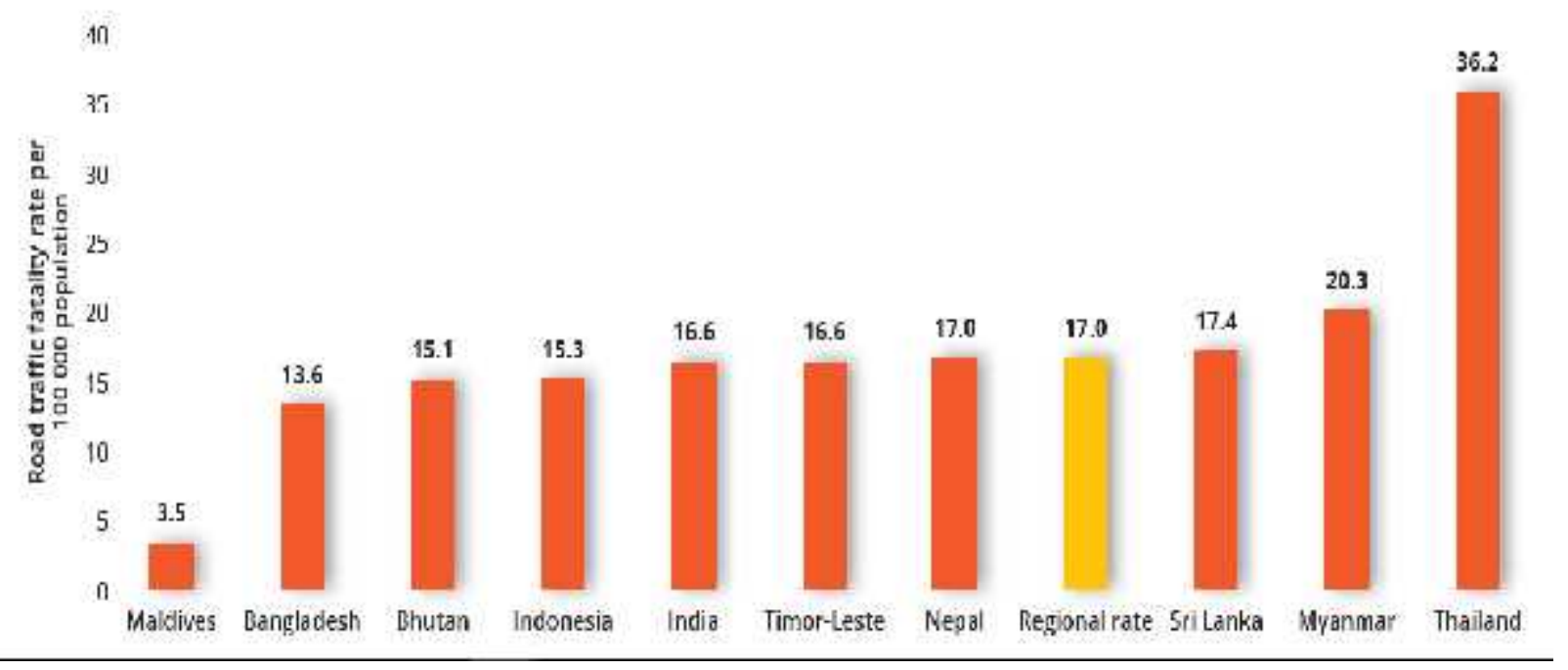

Gambar 4. Angka Kematian Akibat Kecelakaan Lalu Lintas per 100.000 Penduduk. ${ }^{3}$

Sebagai sebuah negara berkembang dengan jumlah penduduk ke empat terbanyak di dunia, angka kejadian kecelakaan lalu lintas di Indonesia menunjukkan kecenderungan yang fluktuasi sejak tahun 1970 sampai dengan tahun 2017. Angka kecelakaan lalu lintas meningkat secara signifikan pada dekade pertama yaitu dari total 19.093 kasus pada tahun

1970 menjadi 51.385 kasus pada tahun 1981. Peningkatan ini diikuti dengan menigkatanya jumlah kematian, cedera berat dan cedera ringan akibat kecelakaan lalu lintas. Pada periode selanjutnya yaitu dari tahun 1981 sampai dengan tahun 2002, angka kejadian kecelakaan lalu lintas mengalami penurunan secara drastis menjadi 12.267 kasus pada tahun 2002. Namun demikian, angka kematian akibat kecelakaan lalu lintas menunjukkan kondisi yang relatif tetap, sehingga dampak dari kecelakaan lalu lintas terhadap angka kematian adalah sangat besar. Pada dekade terakhir, angka kejadian kecelakaan lalu lintas menunjukkan peningkatan yang sangat signifikan mencapai angka 109.311 pada tahun $2010 .{ }^{10}$

Berdasarkan laporan Statistik Transportasi Darat 2017, angka kejadian kecelakaan lalu lintas yang terjadi hingga tahun 2017 selalu berada di atas 100.000 kasus setiap tahunnya kecuali pada tahun 2014 dan 2015 yang berada pada angka mendekati angka 100.000 (Tabel 1). Meskipun demikian, penurunan dan peningkatan yang terjadi selama periode tersebut terlalu siginifkan setiap tahunnya. ${ }^{11}$ Kecenderungan fluktuasi yang terjadi pada jumlah kasus kecelakaan lalu lintas selama periode 1970 sampai dengan 2017 memberikan dua kemungkinan, yaitu (1) penginkatan yang terjadi merupakan peningkatan yang nyata dari jumlah kasus kecelakaan lalu lintas akibat meningkatnya jumlah kepemilikan kenderaan bermotor, atau (2) kemungkinan adanya peningkatan dalam sistem laporan yang dibuat, sehingga mampu menurunkan angka kasus yang tidak dilaporkan pada setiap tahunnya 
(under-reporting cases). ${ }^{10}$

Tabel 1. Jumlah Kecelakaan, Korban, dan Kerugian Materi, Tahun 2013-2017. ${ }^{11}$

\begin{tabular}{lcccccc}
\multicolumn{1}{c}{ Rincian } & $\mathbf{2 0 1 3}$ & $\mathbf{2 0 1 4}$ & $\mathbf{2 0 1 5}$ & $\mathbf{2 0 1 6}$ & $\mathbf{2 0 1 7}$ & \multicolumn{2}{c}{$\begin{array}{c}\text { Pertumbuhan } \\
\text { per Tahun }\end{array}$} \\
\multicolumn{1}{c}{$(\mathbf{1 )}$} & $(2)$ & $(3)$ & $(4)$ & $(5)$ & $(6)$ & $(7)$ \\
Jumlah Kecelakaan (Kasus) & 100.106 & 95.906 & 98.970 & 106.644 & 103.228 & 0,77 \\
Korban Meninggal (Orang) & 26.416 & 28.297 & 26.495 & 31.262 & 30.568 & 3,72 \\
Luka Berat (Orang) & 24.416 & 26.840 & 23.937 & 20.075 & 14.395 & $-12,37$ \\
Luka Ringan (Orang) & 110.448 & 109.741 & 110.714 & 120.532 & 119.945 & 2,08 \\
Kerugian Materi & 255.864 & 250.021 & 272.318 & 229.137 & 215.446 & $-4,21$ \\
(Juta Rp) & & & & & &
\end{tabular}




\section{Faktor Resiko Terjadinya Kecelakaan Lalu Lintas}

Ada beberapa faktor resiko yang berkontribusi untuk meningkatkan angka kejadian kecelakaan lalu lintas. Faktor resiko tersebut bisa dikatagorikan menjadi: (1) Status Sosio- ekonomi masyarakat secara umum; (2) kebiasaan pengguna jalan raya; (3) faktor lingkungan daerah setempat.

\section{Status Sosio-ekonomi Masyarakat}

Masyarakat, terutama yang berdomisili di negara dengan pendapatan rendah dan menengah, umumnya mempunyai jenis kenderaan roda dua atau tiga jika dibanding mereka yang mempunyai kenderaan roda empat atau lebih. Kenderaan tersebut biasanya digunakan untuk tujuan bekerja atau keperluan keluarga lainnya.. Berbeda halnya dengan kondisi masyarakat yang berada di negara maju, mereka lebih memilih untuk mengenderai kenderaan roda empat untuk kebutuhan keluarga dan kenderaan roda dua untuk aktivitas senggang atau rekreasi. Kondisi seperti ini dipengaruhi oleh status socio-ekonomi dari masyarakat, terutama berhubungan dengan pendapatan masyarakat secara umum. ${ }^{12}$

Pada tahun 2013 tercatat ada lebih dari 104,2 juta kenderaan bermotor di Indonesia. Pengguna kenderaan roda dua dan roda tiga mencapai $81 \%$ lebih jika dibanding dengan masyarakat yang menggunakan kenderaan roda empat yang hanya sekitar $10 \%$. Sisanya adalah pengguna truk berat dan bus. ${ }^{7}$ Jumlah ini terus meningkat setiap tahunnya hingga mencapai angka lebih dari 138,5 juta kenderaan bermotor pada tahun 2017 dengan angka pertumbuhan sekitar 7,40 \% setiap tahunnya. ${ }^{7}$ Dengan besarnya jumlah kenderaan bermotor tipe roda dua, kondisi ini memberikan dampak yang signifikat terhadap tinginya angka kecelakaan lalu lintas dan kematian yang diakibatkan oleh kecelakaan tersebut. Tercatat lebih dari 60\% dari total kecelakaan lalu lintas di Indonesia pada tahun 2013 berhubungan dengan kenderaan roda dua. ${ }^{13}$ Persentase ini meningkat secara signifikan pada tahun berikutnya yaitu mencapai $71 \%$ atau sebesar 108.883 kasus dari total kecelakaan lalu lintas pada tahun $2014 .{ }^{14}$

\section{Kebiasaan Pengguna Jalan Raya}

Kebiasaan dari pengguna jalan raya teruma pengemudi kenderaan bermotor menjadi faktor yang berperan terhadap peningkatan atau penurunan angka kejadian kecelakaan lalu 
lintas. Banyaknya pengendara yang tidak memperhatikan keamanan dalam berkenderaan menjadi pemicu tingginya angka kejadian dan fatalitas dari suatu kecelakaan lalu lintas. Abbas, Hefny, dan Abu Zidan menyatakan bahwa memakai helm standar bagi pengguna kenderaan roda dua mampu menurunkan resiko kematian hingga $40 \%$ dan resiko cedera berat mencapai $70 \% .{ }^{15}$ Di Indonesia, pelanggaran yang paling sering terjadi dikalangan pengendara sepeda motor adalah tidak memakai helm saat berkenderaan. Sebagaimana laporan yang disampaikan oleh Polda Jatim pada tahun 2010 yang dikutip oleh Marselius dalam jurnalnya terkait pelanggaran yang paling sering terjadi dikalangan pengendara sepeda motor. Pengendara yang tidak memakai helm memiliki presentase sebesar 51\% dari total pelanggaran dan diikuti dengan penggaran menerobos lampu merah lebih dari $24 \% .{ }^{16}$ Kedua jenis pelangaran ini memberikan dampak yang sangat signifikan terhadap kejadian kecelakaan lalu lintas.

Selain itu, mengenderai kenderaan dengan kecepatan di atas kecepatan maksimum juga menjadi perhatian penting bagi pengendara karena mampu menimbulkan resiko terjadinya kecelakaan lalu lintas. Berdasarkan laporan dari Korp Lalu Lintas Polri (Korlantas) tahun 2019, menyatakan bahwa pelanggaran batas kecepatan maksimum kenderaan terutama terjadi pada pengendara sepeda motor mempunyai persentase yang tinggi dan perlu mendapatkan perhatian khusus dari semua masyarakat. ${ }^{17}$ Kesadaran berkendaraan dengan aman tentu berkaitan dengan tingkat pendidikan dari masyarakat itu sendiri. Semakin tinggi tingkat pendidikan masyarakat dan taraf ekonomi yang semakin bagus berpengaruh terhadap kepatuhan dalam mematuhi peraturan lalu lintas. Hal ini dibuktikan oleh penilitian yang dilakukan oleh Putranto terhadap pengendara mobil di Wilayah Jakarta. Penelitian tersebut menjelaskan bahwa ada sekitar 78\% pengendara mobil menggunakan sabuk pengaman, dan kebanyakan dari mereka adalah masyarakat yang mempunyai pendidikan dan ekonomi yang bagus. ${ }^{18}$

\section{Faktor Lingkungan}

Selain faktor sosio-ekonomi, kelalaian dari pengguna jalan, dan ketidaklayakan kenderaan bermotor, faktor lingkungan memiliki pengaruh yang besar terhadap terjadinya kecelakaan lalu lintas dan mengakibatkan meningkatnya angka kematian (mortality rate) dan kecacatan (Disability-Adjusted Life Years [DALYs]) yang ditimbulkan. Peningkatan jumlah kenderaan bermotor tanpa diikuti oleh peningkatan infrasturktur transportasi seperti jalan, 
lampu lalu lintas pada setiap persimpangan, tempat jalan khusus bagi pejalan kaki dan sepeda akan menimbulkan masalah yang besar terhadap rencana penurunan angka kejadian kecelakaan lalu lintas. Berdasarkan laporan Badan Pusat Statistik tahun 2018, peningkatan infrasturktur jalan hingga tahun 2017 mencapai 539.353 km. Sedangkan peningkatan jumlah kenderaan mencapai 138,5 juta lebih kenderaan pada tahun 2017 atau terjadi peningkatan lebih dari 5 juta kenderaan setiap tahunnya. ${ }^{19}$ Kondisi ini menjadi permaslahan tersendiri terhadap peningkatan angka kecelakaan lalu lintas.

\section{Kelompok yang Rentan terhadap Kecelakaan Lalu Lintas}

Kecelakaan lalu lintas yang terjadi melibatkan beberapa kelompok masyarakat. Ada beberapa kelompok masyarakat yang memiliki kerentanan tinggi terhadap kecelakaan lalu lintas sehingga menjadi perhatian khusus bagi semua pihak terutama pemerintah dalam rangka menciptakan lingkungan yang aman dan nyaman. Hal ini sesuai dengan poin (11.2) SDGs yang menargetkan pada tahun 2030 adanya kemudahan dalam mengakses sistem transportasi yang aman, terjangkau, dan berkelanjutan bagi semua orang, peningkatan keamanan jalan, terutama dengan memperluas jangkauan transportasi publik, dengan memberikan perhatian khusus terhadapa kelompok yang rentan seperti wanita, anak-anak, penyandang disabilitas, dan orang lanjut usia. ${ }^{1}$ Indonesia merupakan salah satu dari tiga negara di Kawasan Asia Tenggara yang mebuat kebijakan nasional dalam rangka melindungi kelompok yang rentan terhadap kecelakaan lalu lintas yaitu dengan mempromosikan masyarakat untuk lebih memilih berjalan kaki, bersepeda, menggunakan trasnportasi umum dan juga memisahkan jalur bagi mereka. ${ }^{20}$

\section{Upaya Pencegahan Terjadinya Kecelakaan Lalu Lintas}

Kematian akibat kecelakaan lalu lintas merupakan suatu peristiwa yang bisa dihindari atau bisa diminimalisir. Untuk mengurangi angka kejadian kecelakaan lalu lintas dan dampak yang diakibatkan, perlu adanya peran serta dari semua pihak terkait mulai dari pemerintah, baik eksekutif maupun legislatif, praktisi kesehatan, akademisi, dan juga masyarakat umum. Pemerintah Indonesia dalam rangka menurunkan angka kecelakaan lalu lintas sudah melakukan banyak hal, terutama berkaitan dengan regulasi serta implementasi dari regulasi tersebut. Sebagaimana disebutkan dalam Global Status Report on Road Safety 2015 bahwa 
Indonesia sudah menetapkan regulasi dalam rangka melindungi pengguna jalan yaitu dengan menetapkan perturan batas kecepatan maksimum kenderaan secara nasional, aturan bagi pengendara yang mengkonsumsi alkohol, kewajiban untuk memakai helm bagi pengendara sepeda motor dan penumpang dengan pencapaian hingga $80 \%$ dari total pengendara dan $52 \%$ penumpang sepeda motor menggunakan helm saat berkendara, kewajiban memakai sabuk pengaman bagi pengendara roda empat, aturan penggunaan alat telekomunikasi bagi 
pengendara saat berkendaraan, dan aturan bagi pengendara yang menggunakan obat-obatan. ${ }^{7}$ Meskipun penerapan aturan yang ada belum maksimal ditandai dengan masih adanya beberapa aturan yang belum disahkan seperti kewajiban penggunaan kursi pengaman bagi anak-anak, kewajiban penggunaan sabuk pengaman bagi penumpang yang duduk di kursi bagian belakang dan membatasi anak-anak untuk duduk di kursi bagian depan, usaha yang dilakukan oleh pemerintah sudah menunjukkan adanya perhatian khusus terhadap tinginya angka kecelakaan lalu lintas dan dampak yang ditimbulkannya.

Selain itu, dalam rangka mendukung program Decade of Action for Road Safety 20112020, sejak tahun 2011 Indonesia sudah mencanangkan program jangka panjang yang tertuang dalam Rencana Umum Nasional Keselamatan (RUNK) 2011-2035 yang bertujuan untuk menurunkan angka kecelakaan lalu lintas. Ada 5 pilar utama dari RUNK 2011-2035, yaitu: (1) terlaksananya manajemen keselamatan yang baik; (2) terciptanya jalan yang lebih aman bagi para pengguna; (3) lahirnya kenderaan yang lebih aman untuk digunakan; (4) terciptanya masyarakat yang lebih aman; dan (5) upaya penanganan kasus kecelakaan yang komprehensif. $^{21}$

\section{Kesimpulan}

Kecelakaan lalu lintas merupakan masalah utama baik di negara berkembang maupun negara maju. Besaran permasalahan yang ditumbulkan oleh kecelakaan lalu lintas dan dampak yang terjadi berupa tingginya angka kematian (mortality rate), kematian dini akibat cedera (YLLs) dan kecacatan lama yang ditimbulkan (DALYs) akan meningkatkan beban serta kerugian dalam bidang ekonomi suatu pemerintahan. Keterlibatan semua pihak dalam rangka menurunkan angka kecelakaan lalu lintas merupakan suatu tindakan yang menjadi prioritas untuk dilaksanakan. Terlebih dengan adanya target yang besar untuk menurunkan angka kecelakaan dan menciptakan lingkungan yang aman, serta akses yang mudah terhadap transportasi sebagaimana tertuang dalam Tujuan Pembangunan Berkelanjutan (SDGs) 2030 akan terealisasi dengan maksimal. 


\section{REFERENSI}

1. United Nation. Transforming Our Wolrd: the 2030 Agenda for Sustainable Development.

2. World Health Organization. Global Status Report on Road Safety 2018: Summary. Geneva: WHO, 2018

3. World Health Organization. Road Safety in the Southeast Asia Region 2015. New Delhi: WHO Regional Office for South-East Asia, 2016

4. Wolrd Bank. World Development Indicator Database 2019.

5. The Organization for Co-operation and Development (OEDC). Injuries in Road Traffic Accidents: Definition, Sources and Methods. 2014

6. Peraturan Kepala Kepolisian Negara Republik Indonesia No. 15 Tahun 2013. Tata Cara Penanganan Kecelakaan Lalu Lintas. Available at: http://ditjenpp.kemenkumham.go.id/arsip/bn/2013/bn1528-2013.pdf

7. World Health Organization. Global Status Report on Road Safety 2015. Italy: WHO, 2016

8. Institute for Health Metrics and Evaluation. Findings from the Global Burden of Disease Study 2017. Seatle. WA: IHME, 2018

9. Ameratunga,S., Hijar,M., Norton, R. Road-Traffic Injuries: Confronting Disparities to Address a Global-Health Problem. Lancet 2006(367). Pp 1533-1540

10. Nahri., Soehodho, S., Tjahjono, T. Changes in Traffic Safety Policies and Regulations in Indonesia (1950-2010). International Association of Traffic and Safety Sciences 2012. Pp 34-72

11. Badan Pusat Statistik. Statistik Transportasi Darat 2017. BPS RI. 2017

12. Sharma, B. R. Road Traffic Injuries: A major Global Public Health Crisis. Public Health 122. Pp 1399-1406

13. Kirono, C. Mewujudkan Keselamatan Jalan Oleh Pengendara Sepeda Motor Melalui Pembenahan Sektor Hilir. Korp Lalu Lintas RI, 2014

14. The Association of South East Asia Nation. ASEAN Road Safety Startegy 2016. Jakarta: Asean Secretariat, 2016

15. Abbas, A.K., Hefny, A.F. \& Abu-Zidan, F.M. Does wearing helmets reduce motorcycle- related death? A global evaluation. Accident Analysis and Prevention 2012. $49,249-252$ 
16. Tondok, M S, Ficky Ardiansyah, Ayuni. Intensi Kepatuhan Menggunakan Helm Pada Pengendara Sepeda Motor: Aplikasi Teori Perilaku Terencana. Repository.ubaya.ac.id. 2012.

17. Korp Lalu Lintas RI. 5 Pelanggaran dengan Jumlah Tertinggi. 2019, Available at: http://korlantas-irsms.info/graph/violationTypeData

18. Putranto, L. S. Characteristics of Seat Belt Use in Jakarta. Proceeding of the Eastern Asia Society for Transportation Studies 2005. Pp 1963-1972.

19. Badan Pusat Statistik RI. 2013.

20. World Health Organization. Status Keselamatan Jalan di WHO Regional Asia Tenggara 2013. WHO Regional Office for South East Asia: New Delhi, 2013.

21. Rencana Umum Nasional Keselamatan Jalan 2011-2035. Available at: http://perpustakaan.bappenas.go.id/lontar/file?file=digital/117404-[ Konten_]Konten\%20C7887.pdf 